\title{
Tropical Gothic: arts, humanities and social sciences
}

\author{
Anita Lundberg, Katarzyna Ancuta \& \\ Agnieszka Stasiewicz-Bieńkowska
}

\begin{abstract}
James Cook University, Australia; Chulalongkorn University, Thailand; Jagiellonian University, Poland
\end{abstract}

\begin{abstract}
The Gothic is undergoing a pronounced resurgence in academic and popular cultures. Propelled by fears associated with massive social transformations produced by globalisation, the neoliberal order and environmental uncertainty tropes of the Gothic resonate. The gothic allows us to delve into the unknown, the liminal, the unseen; into hidden histories and feelings. It calls up unspoken truths and secret desires.

In the tropics, the gothic manifests in specific ways according to spaces, places, cultures and their encounters. Within the fraught geographies and histories of colonisation and aggression that have been especially acute across the tropical regions of the world, the tropical gothic engages with orientalism and postcolonialism. The tropics, as the region of the greatest biodiversity in the world, is under enormous stress, hence tropical gothic also engages with gothic ecocriticism, senses of space, landscape and place. Globalisation and neoliberalism likewise impact the tropics, and the gothic imagery of these 'vampiric' capitalist forces - which impinge upon the livelihoods, traditions and the very survival of peoples of the tropics - is explored through urban gothic, popular culture, posthumanism and queer theory.
\end{abstract}

As the papers in this special issue demonstrate, a gothic sensibility enables humans to respond to the seemingly dark, nebulous forces that threaten existence. These papers engage with specific instances of Tropical Gothic in West Africa, the Caribbean, Latin America, Southeast Asia, northern Australia, and the American Deep South.

Keywords: Tropical Gothic, Gothic Studies, Southeast Asia, West Africa, Caribbean, Latin America, Northern Australia, American Deep South 


\section{Tropical Gothic}

A

t first glance, the term "Tropical Gothic" sounds a lot like an oxymoron, since in popular understanding the genre is often synonymous with its early settings of bleak European wilderness battered by howling winds and tumultuous storms. In contrast, Tropical Gothic heroes and heroines have vacated traditional eerie castles and chilling wind-swept moors to take up residence in haunted plantation houses, overgrown bayous, mysterious jungles and exuberant tropical cities, where the horrific and the uncanny not only lurk in the shadows but occupy open, sun-drenched spaces alongside humans. Or, as Daniel Serravalle de Sá (2010) notes, Tropical Gothic conjures up opposing imaginaries of solar and gloom in the one concept.

The tropics, however, offer much more than just geographical constructs with their exoticised landscapes, cityscapes and climate. Justin D. Edwards and Sandra Guardini Vasconcelos argue that the tropicalisation of the Gothic genre appropriates, problematises and adapts it to fit the new locale within its social, cultural and political contexts. Through these adaptations, Tropical Gothic "re-emerges to underscore politically charged ghosts and monsters that return the colonial Other to the center of Empire and foreground the unease and complications of Gothic figures" (2016, p. 2). The glaring, hot and humid landscapes of the tropics cannot stave off monsters. They move in and take possession. Some, in fact, have always been here. Gothic feeds off autochthonous popular culture, folklore, and beliefs - spawning hybrid monstrosities in its wake.

Simultaneously narrated as a paradisiacal terrain of sensuality and opulent beauty, and a hellish space of hidden terrors and masked monstrosities (see Edwards \& Vasconcelos 2016, p. 4; Stasiewicz-Bieńkowska, 2017), the tropics have long been employed as an expression for Western narratives of cultural fears and desires for domination. Imagined and Gothicised as the birthplace of the ultimate Other-one to be "civilised" or eradicated by modern Western forces - tropical and sub-tropical milieux have been used as a vehicle for imperialist and colonial discourses. This rhetoric was often reflected in the accounts of early travellers and adventurers; it manifested in Cold-War era U.S. film productions where tropical (often South American) predators waited to be defeated by North American explorers and scientists (Höglund, 2016, p. 63); and it emerged in popular past imageries of the tropical jungle as a liminal terrain of mystery, monstrosity and feral desires (Menadue, 2017). Tropical Gothic incorporates such othering discourses, but it also subverts them by situating them alongside reimaginings of the relationship between the 
Western/Northern (as centre) and the Tropics (as marginal). In contrast, Tropical Gothic texts are read in the context of resistance to stereotyping discourses that exoticise the tropical Other, since the idea of appropriating, adapting, or transforming the genre implies that the colonised subject is given agency to effectively re-write the story.

This relationship between "the colonial centre" and "the colonised Other" is complex and highly dynamic. The tropical and subtropical regions encompass a multitude of diverse cultures, whose modernity was to a large extent shaped in relation to European colonialism and American imperialism. While the intricacies of power cannot be solely viewed alongside the axes of West versus East or North versus South, a great majority of tropical states were at some point colonised by European forces, albeit these processes impacted them in diverse ways. Impoverished by the colonial rule, many of these countries have found themselves in continuing exploitative relationships with dominant neighbours. The late twentieth century saw the emergence of new centres to which the tropics were realigned - many tropical countries became the site of U.S. political/military intervention, exposed to Americanisation and later globalisation, while some emerged as regional powers themselves. Europe and the United States were not the only centres of imperial ambition - a significant part of the Asian tropics was also shaped by twentieth-century Japanese militarism, which liberated countries from European colonialists only to impose another form of harsh control. In the twenty-first century, the Asian tropics have additionally grown economically dependent on China and culturally invested in Japanese and Korean trends.

Tropical Gothic also contests any notion that this genre evolved entirely in response to its European/North American predecessor. Such an approach would suggest that authors must be familiar with and consciously relate to earlier Gothic texts. While there is no denying that at least some cultural productions can be seen as a conscious hybridisation of local and foreign Gothic influences, "feeding off each other to produce new crosscultural monstrosities" (Byron, 2008, p. 33), Gothic has never been a domain of one culture. As Andrew Hock Soon Ng rightly points out, "transgressing taboos, complicity with evil, the dread of life, violence, and the return of the repressed [...] are not specific to any culture or people, but are experienced by all throughout history" (2008, p. 1). Tropicalising Gothic, should not only be seen as a process through which the dominant Gothic forms are adapted, transformed or resisted, but also as an opportunity to revisit our conceptualisation of Gothic and examine its transcultural potential. European Gothic arose in response to Enlightenment philosophies and Christian values. Tropical Gothic, however, is a significantly more inclusive genre, with its texts referencing culturally 
diverse worldviews and philosophical orientations. Examining these texts allows us to move beyond the tired dichotomy of West versus East, or North versus South and focus on the transnational, transcultural and trans-tropical.

In the contemporary Tropical Gothic genre the Gothic preoccupation with notions of (un)belonging, racialised identity, excessive or dangerous sexuality, violence, the body and its boundaries, memory and the burden of the clandestine past on the uncertain, crumbling present are evoked through the experiences of colonial injustice, the exploitation of Indigenous peoples, slavery, racism and resistance against the practices of imperialism - all of which are shared by many tropical and sub-tropical regions. Thus, the Tropical Gothic of today provides a space of reflection upon the unique social, historical, political, cultural and environmental conditions of the tropics.

\section{Tropics and Gothics}

The papers collected together for this special issue examine manifestations of Tropical Gothic across a range of regions and locations of the tropical and subtropical world. Beginning with West Africa, several papers follow African slave legacies through the Caribbean - including Haiti, Curaçao, and Jamaica. African and Caribbean influences are also reflected in papers arising from the American Deep South and the urban gothics of New Orleans. In Colombia, Latin America, the influence of Tropical Gothic aesthetics and literature is likewise set within the urban gothic. Tropical Gothic also manifests in Southeast Asia, where papers address the legacies of war in Vietnam and the impact of rapid modernisation of Bangkok, Thailand. Continuing across to Australia, specific aspects of an Australian Tropical Gothic are explored through landscapes and colonial histories in the subtropical Eastern hinterland and the northern wet and dry tropics of the continent's top end.

The tropics, however, is never merely a geographical construct. The imaginary of the tropics and its Gothic implications, also emerges out of the conceptual spaces of ethnography, religious ritual, folklore, literature, film, television and the arts - as well as through cityscapes, landscapes, the environment and climate. In this collection, Tropical Gothic is explored through disciplinary and interdisciplinary fields within the arts, humanities and social sciences, including: Anthropology, History, Postcolonial Studies, Literary Criticism, Folklore Studies, Ecocriticism, Queer Theory, Posthumanism, Cultural Studies, Popular Culture, the Visual Arts and Gothic Studies. 
In the first paper, Eric Montgomery offers an anthropological critique of popular conceptions of the Gothic and their appropriation and misconception of Voodoo religion. His paper investigates the history of Voodoo in Africa and Haiti and aims to counter mystifying aspects of the religion as it is portrayed in contemporary Gothic popular culture. As Montgomery clarifies, the paranormal and supernatural is part of quotidian life for devotees of Vodun in Western Africa and Vodu in Haiti. The mystery and macabre, the spirits and supernatural characters, central to the cosmological belief and ritual practices of Voodoo, are likewise essential tropes of the Gothic. However, the two are founded on different premises, and their conflation in popular culture is problematic. Vodun/Vodu is not equivalent to American zombie Gothic. To conflate Gothic and Voodoo leads to a racialised Eurocentric hegemony that devalues an ancient indigenous religion.

John Armstrong also offers a cultural critique in his exploration of notions of the Gothic in contemporary Vietnamese postwar fiction. He states that there has been a dearth of English-language appraisals of Vietnamese literature of the 'American War' (the term used in Vietnam) in comparison to thousands of critical studies of American writing on the 'Vietnam War' (as it is called in Anglo countries). He notes that there is a disparity in understanding of the notions of ghosts of war between Vietnamese and American cultures. In Vietnam there remains a public belief in war ghosts as manifestations of wandering spirits, who, due to violent death, cannot make the transition from the living world to that of the spiritual. From the Vietnamese postwar fiction, published and translated since the 1990s, Armstrong carries out a close reading of novels by Bao Ninh and Duong Thu Huong and short stories by Le Minh Khue, Ho Anh Thai, Ngo Tu Lap and Phan Hy Dong. He analyses how local customs of the dead combine with Gothic features to create a specific Tropical Gothic (including, in this instance, War Gothic and Jungle Gothic) that resists ideologies that portray the war through traditional nationalistic and heroic tropes.

An Urban Tropical Gothic is the locus of papers by Felipe Gómez G., Katarzyna Ancuta and Verena Bernardi. The three papers explore specific notions of the Gothic and the city as they arise through moving images and literature from Colombia in Latin America, Bangkok in Thailand, and New Orleans in the Deep South of America.

Felipe Gómez G. discusses the development of Tropical Gothic as a rich legacy of the interdisciplinary collective El Grupo de Cali, which was active in Colombia in the 1970s. The collective was led by Andrés Caicedo Estela, a writer and film critic, along with the 
filmmakers Carlos Mayolo and Luis Ospina. As Gómez articulates, conventions of literary and cinematic gothic undergo a process of transculturation and tropicalisation in $\mathrm{El}$ Grupo's incarnation of Tropical Gothic. The site of this incarnation is the aesthetic and literary exploration of the experience of the modern tropical Latin American city - a dark and savage aesthetic where urban youth are both perpetrators and victims of violence. This urban monstrosity is linked with cinematic tropes from Hollywood B-series vampire movies, local myths and legends, and the reality of racial, sexual, political and socioeconomic violence. In the literature by Caiceda, urban youth are placed in countercultural scenes incorporating popular culture elements of film, music and drugs.

Bangkok as Gothic metropolis, is explored in Katarzyna Ancuta's paper 'Love, death and laughter in the city of different angels'. Analysing SP Somtow's novel The Other City of Angels (2008), she states that the author portrays urbanity stuck between illusion and reality, where dreams and nightmares come to life. In the novel, the city is simultaneously spiritual and material - a temple to consumerism filled with fortune tellers and high society serial killers. Against this backdrop - rendered so full of peculiarities that the reader questions its existence - the plot offers a modern retelling of the Gothic tale of Bluebeard. In Somtow's novel, the wife-murdering Bluebeard and his castle of rooms filled with dark secrets, is translocated to the tropical exuberance of 1990s "miracle economy" Bangkok. As Ancuta notes, true to its Gothic origins, the story is filled with romance, terror, and laughter. It is to this dark humour and Gothic grotesqueries that Ancuta turns her attention, analysing how Somtow uses these elements as a strategy to exoticise the city for foreign readers by simultaneously reinforcing and deconstructing Western stereotypes of the Orientalist city of 'temples and prostitutes'. Furthermore, the comic-grotesque elements problematise the social inequality and class divisions that are viewed as inherent to Thai culture - and which are exacerbated by the consumerism of contemporary Thai society.

Verena Bernardi moves our attention to the city of New Orleans in the American Deep South. Through a close analysis of The Originals (2013-2018), she demonstrates how the television series creates a supernatural mirror image of American society by portraying how the different communities of vampires, werewolves and witches struggle for power and spatial demarcation in New Orleans and its surrounding bayous. She argues that this gothicised New Orleans plays a crucial role in constructing a space in which the various communities operate in a posthuman context. These supernatural creatures are no longer portrayed as fear-inducing monsters. Instead, their depiction tends to adopt human qualities to confront the audience with the problems of contemporary society and politics. Bernardi's paper articulates how the posthuman characteristics of the protagonists - and 
their spatial placement in the subtropical landscape of New Orleans and its surrounding bayous - reflects contemporary sociopolitical concerns and brings aspects of the Urban Gothic and tropicality closer to the audiences' reality. Ultimately, in this Gothicised capital of the subtropical Deep South of America hegemonic discourses and practices of discrimination and spatial separation are reflected and challenged.

Also set in the American Deep South, Jennifer Dos Reis Dos Santos' paper, 'Hidden Voices: Slavery and Folklore of the American South', argues that African American folklore embodies themes of the Tropical Gothic and Southern Gothic through the deeper meanings that the tales hold within the various layers of their plots. The folklore of the American South both hides and reveals the darkness of the slavery period and its implications for contemporary African Americans. She analyses two folklore collections: Uncle Remus, His Songs and His Sayings: The Folk lore of the Old Plantation by Joel Chandler Harris, and From My People: 400 Years of Folklore by Daryl Cumber Dance. These collections illuminate the ways in which West African oral traditions became a source of empowerment, courage and wisdom for enslaved African Americans. She argues that the folk stories were a means of silent resistance and that their preservation and retelling are significant for the cultural heritage of African Americans.

Moving the reader to the Caribbean, the following two papers engage Tropical Gothic through the omnipresence of island environments. The first paper, set on Curaçao, is concerned with postcolonialism and ecocriticism and offers a tropical encounter with Ecogothic. The second paper, suffused in Jamaica's ruinate, engages postcolonialism, queer theory and ecocriticism, and serves to queer Tropical Gothic.

Daniel Arbino's paper, set on the Dutch Caribbean island of Curaçao, uses the lens of ecocriticism. He argues that Curaçaoan author Tip Marugg's use of ecogothic articulates a postcolonial sense of insular alienation for his white protagonists. Through two of Marugg's stories - Weekend Pilgrimage (1957) and The Roar of Morning (1988) - Arbino demonstrates how the depiction of the Dutch Caribbean environment as decadent and hostile creates an atmosphere in which the white characters become unmoored from the colonial and neocolonial structures that empowered them - racial hierarchy, the oil industry, globalisation, and tourism. The Gothic imaginary of the natural environment in these stories is redolent with haunting winds, suicidal birds, sea monsters and rampant destruction. To explore how ecocriticism is implicated with notions of (un)belonging, race and class in Curaçao, Arbino undertakes a comparative analysis with Frank Martinus Arion's novel Double Play (1998). He concludes that while Marugg's white characters are 
often the target of the island's ecosystem, Arion's Afro-Curaçaoan protagonist experiences a different interaction with the natural environment - one which embraces a sense of belonging and situates Afro-Curaçaoans as stewards of the island's future.

Gregory Luke Chwala's paper is located in a different Caribbean, that of Jamaica's ruinate. The Jamaican term ruinate describes lands, once cleared for agriculture, that have been reclaimed by jungle growth. The term likewise signifies the taking back of land by Jamaicans from British colonialists and American imperialists. Chwala's interest is in the ways postcolonial Gothic conventions are used to articulate a convergence of gender, race, sexuality, capitalism, colonialism, and environment. Taking up Michelle Cliff's No Telephone to Heaven (1987), he demonstrates how the racialised and classed queer and trans characters of the novel transgress colonial bordered clearings through reappropriating spaces and bodies in Jamaica's ruinate. He furthermore analyses how the Afro-Caribbean people in the ruinate challenge imperialism by forming a coalition that embraces trans leadership. The renegotiate of human agency in the ruins of empire - as the metaphor of the ruinate evokes - explores non-hierarchical relationships between queer/non-queer characters and the land.

Likewise set in the Caribbean and concerned with Afro-Caribbean slavery, Emmy Herland's paper undertakes a close reading of Gertrudis Gómez de Avellaneda's 1841 Cuban-Spanish Gothic novel Sab. Set in Cuba, the black slave Sab, who is in love with his white mistress, dies just as he finishes writing a letter. As Herland argues, the slave Sab has infused the letter with his presence through the first-person, personal narrative; while ensuring his absence by death. Sab's combined presence and absence turns him into a kind of ghost that haunts those who read his letter - a paradox of the spectre as described by Derrida in Specters of Marx (1993). Offering a Derridean analysis of the resonances of Sab's letter throughout the storyline of the novel, Herland demonstrates how the letter acts to identify Sab - and through him the institution of slavery that he both represents and protests against - as the haunting figure of the novel.

On the vast island-continent of Australia, histories of colonialism and the specifics of landscape, environment and climate permeate a specifically Australian Tropical Gothic. Of the two following papers, the first proposes a Hinterland gothic as the author explores the subtropical excess of South East Queensland. The second, and final paper in this collection, explores Tropical Gothic in the Northern regions of Australia - which comprise both dry and wet tropics - through the visual arts. 
Emma Doolan, proposes that South East Queensland's subtropical hinterlands - the mountainous, forested country lying between the cities along the coast and the Great Dividing Range - are sites of a regional variation of Australian Gothic. She specifically draws our attention to how the atmospheres and metaphors of these regional landscapes, climates, and histories create a Hinterland Gothic. In an analysis of the writings of Eleanor Dark, Judith Wright, Janette Turner Hospital, and Inga Simpson, she reveals how the hinterlands are evoked as regions "beyond the visible and known" where the subtropical climate gives rise to unruly and excessive nature. Excess in Gothic literature, Doolan reminds us, is related to the unspeakable or the repressed. By bringing Gothic, postcolonial and ecocritical perspectives to bear on the literature of the hinterlands, Doolan reveals a preoccupation with the regions' repressed histories of colonial violence written on the landscape through Gothic metaphors.

In the final paper of this collection, Mark Wolff turns our attention to the Northern Tropics of Australia. He reminds us that the the field of Gothic Studies concentrates predominately on literature, cinema and popular culture. The aim of Wolff's paper is an historical exploration of an Australian Tropical Gothic through the visual arts. Wolff notes that there is a dearth of studies that address the Gothic in the visual arts in Northern or Tropical Australia. Thus, his paper is an exploration, and it starts by situating the vast spaces of Australia as a place of extremes - the sites of appalling and mysterious deaths of famous nineteenth-century explorers, and relentless colonial exploitation and murder of Indigenous peoples. A broad review of mostly European visual arts in Tropical Australia reveals that Gothic themes and motifs tend to centre on aspects of the landscape. During Australia's early colonial period, the Northern landscape is portrayed as a place of uncanny astonishment. An Australian Tropical Gothic reappears for early modernists as a desolate landscape that embodies a mythology of peril, tragedy and despair. Finally, for a new wave of contemporary artists, including some significant Aboriginal and Torres Strait Islander artists, Gothic motifs emerge to animate tropical landscapes and draw attention to issues of environmental degradation and the dispossession of Australian Aboriginal and Torres Strait Islander peoples.

\section{Legacies and Futures}

The range of papers brought together in this special issue is telling. They highlight the varieties of subject matter, as well as stylistic and theoretical approaches that can be explored through the concept of Tropical Gothic. Yet there are common undercurrents that reveal and critique histories of colonialism, imperialism and orientalism; demonstrate 
grave concerns regarding the environment and climate; examine anxieties over globalisation, neoliberalism and consumerism; analyse the politics of race, gender and sexuality; and question what it means to be human/posthuman.

This collection shows how these contemporary concerns can be expressed through Gothic tropes - allowing oral storytellers, writers, artists, film and television producers, social scientists and experts in cultural studies a way to voice and articulate their disquiet in astute observations of society. Gothic Studies is known for its ability to interpret the contemporary world and its historical legacies. It is a field that seeks to bring to light the dark depths of the human condition. Tropical Gothic's sensibility articulates how contemporary concerns that face the world are played out in the tropics and subtropics in specific ways. Significantly this specificity is based in the continuing legacies of colonialism, war and violence - and their ripple on effects to globalisation and neoliberal capitalism. These, in turn, impact race and gender relations, and the environmental crisis.

The Tropical Gothic special issue draws on ideas originally conceived in a previous eTropic issue entitled, 'Tropical Liminal: Urban Vampires and Other Bloodsucking Monstrosities' which reflected upon the gothic implications of "vampires and other monstrosities in relation to the tropical [urban] regions of the world from historical pasts to present-day manifestations, and imaginary tropical futures" (Lundberg \& Geerlings, 2017, p.1). Extending this previous area of analysis to the broader issue of Tropical Gothic allows for a wider scope of papers. In order to accommodate the large range of papers addressing this theme, this special issue will be published in two parts. This first issue concentrates on arts, humanities and social sciences, while the upcoming companion second issue will draw together papers on literature and creative works. 


\section{References}

Byron, G. (2008). “'Where Meaning Collapses': Tunku Halim's Dark Demon Rising as Global Gothic." In A.H.S. Ng (Ed). Asian Gothic (pp. 19-31). Jefferson NC \& London: McFarland.

de Sá, D.S. (2010). Tropical Gothic. Rome, Italy: Arachne.

Edwards, J.D. \& Vasconcelos, S.G. (2016). Tropical Gothic in Literature and Culture: The Americas. New York, NY \& Oxon, UK: Routledge.

Höglund, J. (2016). Consuming the Tropics: The Tropical Zombie Re-eviscerated in Dead Island. In J.D. Edwards \& S.G.T. Vasconcelos (Eds). Tropical Gothic in Literature and Culture: The Americas (pp.87-102). New York, NY \& Oxon, UK: Routledge.

Lundberg, A. \& Geerlings, L. (2017). Tropical Liminal: Urban Vampires \& Other Blood-Sucking Monstrosities. eTropic: electronic journal of studies in the tropics 16 (1), 1-4. http://dx.doi.org/10.25120/etropic.16.1.2017.3574

Menadue, C.B. (2017). Trysts Tropiques: The Torrid Jungles of Science Fiction. eTropic: electronic journal of studies in the tropics $16(1), 125-140$. http://dx.doi.org/10.25120/etropic.16.1.2017.3570

Ng, A.H.S. (2008). "Introduction: The Gothic Visage of Asian Narratives." In A.H.S. Ng (Ed). Asian Gothic (pp. 1-15). Jefferson NC \& London: McFarland.

Stasiewicz-Bieńkowska, A. (2017). Exotic Otherlands, Headquarters of Death: Sub-tropical land- and cityscapes in The Southern Vampire Mysteries. eTropic: electronic journal of studies in the tropics 16(1), 18-20. DOI:

https://journals.jcu.edu.au/etropic/article/view/3566 